\title{
MEFV mutation carriage as possible predisposition factor for the development of Post Pericardiotomy Syndrome (PPS)
}

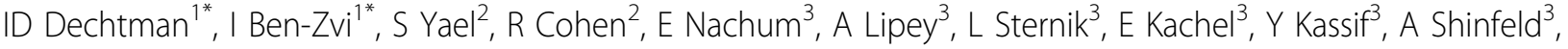 \\ D Spigelstein ${ }^{3}$, J Lavee $^{3}$, E Raanani $^{3}$, A Livneh $^{1}$
}

From 8th International Congress of Familial Mediterranean Fever and Systemic Autoinflammatory Diseases Dresden, Germany. 30 September - 3 October 2015

\section{Background}

PPS is a syndrome, which manifests with pleuropericardial inflammation and occurs in about $15-20 \%$ of patients undergoing surgery, involving the pleura, pericard or both. The pathogenesis of the syndrome is not yet fully understood. Carriage of MEFV mutations may explain the occurrence of this syndrome, which largely overlaps with FMF, in only part of the operated population.

\section{Goal}

To determine whether MEFV mutation carriage may precipitate PPS or affect its phenotype.

\section{Methods}

86 patients who underwent cardiac surgery were studied, 45 of whom developed PPS (study group) and 41 have not (control group). Demographic data (gender, age, region of residence, ethnic origin) and type of surgery were collected. The severity of PPS was evaluated, based on a predefined scale. Genetic analysis determining carriage of one of the three most common MEFV gene mutations (M694V, V726A, E148Q) was performed.

\section{Results}

The rate of women was higher in the PPS group $(p=0.001)$. No significant differences were found between the 2 groups with regards to the rate of mutation carriage. Subgroup analysis for age, ethnic origin and gender also failed to yield significant results. The severity of the PPS in carriers was lower compared to non carriers.

${ }^{1}$ Sheba Medical Center, Internal Medicine F, Ramat-Gan, Israel Full list of author information is available at the end of the article

\section{Conclusions}

Carriage of MEFV mutations does not predispose for the development of PPS. However carriage of MEFV mutations does affect PPS phenotype $(\mathrm{P}<0.05)$.

\section{Authors' details}

${ }^{1}$ Sheba Medical Center, Internal Medicine F, Ramat-Gan, Israel. ${ }^{2}$ Sheba Medical Center, Heller Institute of Medical Research, Ramat Gan, Israel.

${ }^{3}$ Sheba Medical Center, Cardiac Surgery, Ramat-gan, Israel.

Published: 28 September 2015

doi:10.1186/1546-0096-13-S1-P76

Cite this article as: Dechtman et al:: MEFV mutation carriage as possible predisposition factor for the development of Post Pericardiotomy Syndrome (PPS). Pediatric Rheumatology 2015 13(Suppl 1):P76.
Submit your next manuscript to BioMed Central and take full advantage of:

- Convenient online submission

- Thorough peer review

- No space constraints or color figure charges

- Immediate publication on acceptance

- Inclusion in PubMed, CAS, Scopus and Google Scholar

- Research which is freely available for redistribution

Submit your manuscript at www.biomedcentral.com/submit
() Biomed Central 